\section{Forest canopy productivity index}

SIR - Increased carbon dioxide concentrations can stimulate the productivity of terrestrial vegetation and thereby alter the relationships between anthropogenic carbon emissions, atmospheric $\mathrm{CO}_{2}$ concentrations and climate change. This must therefore be taken into account when policy options for climate control are being assessed ${ }^{1,2}$.

The representation of increased $\mathrm{CO}_{2}$ on a global scale should come from models, but the growth and carbon storage of different vegetation types in controlled, $\mathrm{CO}_{2}$-enriched atmospheres must be determined experimentally in order to test assumptions made in such models. Critical mechanistic model components (for example, photosynthesis and transpiration) can be compared with experimental data $^{3}$, but we do not have enough experimental data on the growth of trees to evaluate models of forest responses to rising $\mathrm{CO}_{2}$. Results of the few field experiments that have investigated tree responses beyond the seedling stage are difficult to generalize and extrapolate. I suggest that some of this difficulty derives from the use of plant dry mass as the primary indicator of response. A more robust and conceptually more useful measure of response is the annual production of wood per unit of leaf area, which I refer to here as canopy productivity index (CPI; formerly called growth efficiency ${ }^{4}$ ).

The effect of $\mathrm{CO}_{2}$ enrichment on plant mass has varied widely in the several studies with broadleaf trees (see table). In 1992, we reported that Liriodendron tulipifera trees grown for almost three years in elevated concentrations of atmospheric $\mathrm{CO}_{2}$ showed a sustained increase in photosynthesis rate compared with trees grown in ambient $\mathrm{CO}_{2}$, but with no significant increase in plant dry mass ${ }^{5}$, in marked contrast to the reported responses of Citrus aurantium trees exposed to elevated $\mathrm{CO}_{2}$ under horticultural conditions ${ }^{6}$. The difference in response in these two studies has been taken as evidence that trees will show growth responses only in the presence of adequate nutrients ${ }^{7}$, or attributed to

\footnotetext{
1. Wigley, T. M. L., Richels, R. \& Edmonds, J. A. Nature 379, 240-243 (1996)

2. Friedlingstein, P. et al. Globl Biogeochem. Cycles 9, 541-556 (1995).

3. Woodward, F. I., Smith, T. M. \& Emanuel, W. R. Globl Biogeochem. Cycles 9, 471-490 (1995).

4. Norby, R. J., Wullschleger, S. D. \& Gunderson, C. A. in Carbon Dioxide and Terrestrial Ecosystems (eds Koch, G. W. \& Mooney, H. A.) 1-21 (Academic, San Diego, 1996).

5. Norby, R. J., Gunderson, C. A., Wullschleger, S. D.,

O'Neill, E. G. \& McCracken, M. K. Nature 357, 322-324 (1992).

6. Idso, S. B. \& Kimball, B. A. Globl Biogeochem. Cycles 7, 537-555 (1993)

7. Curtis, P. S., Vogel, C. S., Pregitzer, K. S., Zak, D. R. \& Teeri, J. A. New Phytol. 129, 253-263 (1995).
}

RESPONSE TO ELEVATED $\mathrm{CO}_{2}$ OF DRY MASS AND ANNUAL STEM PRODUCTION PER UNIT LEAF AREA (CPI) OF FIELD-GROWN BROADLEAF TREES

\begin{tabular}{|c|c|c|c|c|}
\hline Species & $\begin{array}{l}\text { Duration of exposure } \\
\text { (growing seasons) }\end{array}$ & $\begin{array}{l}\% \text { Increase in } \\
\text { dry mass }\end{array}$ & $\begin{array}{l}\text { \% Increase } \\
\text { in CPI }\end{array}$ & Ref. \\
\hline L. tulipifera & 2.7 & 18 & 35 & 4,5 \\
\hline \multicolumn{4}{|c|}{$\begin{array}{l}\text { Populus } x \text { euramericana } \\
\text { (Eugenei) }\end{array}$} & 7,11 \\
\hline Low fertility & 1 & 26 & 22 & \\
\hline High fer tility & 1 & 38 & 18 & \\
\hline \multicolumn{5}{|c|}{ Populus $x$ euramericana } \\
\hline (Robusta) & 2 & 44 & 37 & 12,13 \\
\hline \multicolumn{5}{|c|}{ Populus trichocarpa $x$ deltoides } \\
\hline (Beaupré) & 2 & 73 & 22 & 12,13 \\
\hline Fagus sylvatica & 2 & 91 & 31 & 14 \\
\hline Q. alba & 4 & 135 & 37 & 4,9 \\
\hline C. aurantium & 5 & 180 & 33 & 6,15 \\
\hline Average \pm s.d. & & $76 \pm 57$ & $29 \pm 7$ & \\
\hline
\end{tabular}

In each experiment the trees were planted directly in the ground and exposed in open-top chambers to $\mathrm{CO}_{2}$ partial pressures of approximately 350 p.p.m. (ambient) and $650-700$ p.p.m. $C P I s$ of $L$. tulipifera and $Q$. alba were calculated by regression analysis of annual stem mass increment versus leaf area. Other calculations were based on published values of mean stem dry mass or dry mass increment (or a surrogate measure), and leaf area or relative increase in leaf area.

unusual leaf physiology in Citrus $^{8}$. Such explanations are unnecessary, and the nutrient explanation is not robust. We recently reported that Quercus alba saplings exposed to elevated $\mathrm{CO}_{2}$ for four years responded similarly to the Citrus trees, more than doubling in dry mass relative to trees in ambient $\mathrm{CO}_{2}$, even though they were grown in the same exposure chambers and unfertilized soil as the L. tulipifera ${ }^{9}$. Other species have shown intermediate responses (see table).

Despite this apparent divergence of results, which makes generalizations untenable, closer analysis suggests a fundamental similarity in response across these studies. Regardless of the substantial differences in cultural conditions, inherent species characteristics and the final dry mass response, the CPI of broadleaf tree species increases approximately $29 \%$ in response to $\mathrm{CO}_{2}$ concentration increases of 300-350 parts per million (p.p.m.; see table). The large increases in dry mass observed in $Q$. alba and $C$. aurantium were dependent on an increasing leaf area, a response that was established very early in the exposure regime and was compounded over time. Conversely, the limited response of the L. tulipifera was attributed to a relative decline in leaf area. The CPI normalizes the increases in wood accumulation to a

\footnotetext{
8. Amthor, J. S. Globl Change Biol. 1, 243-274 (1995). 9. Norby, R. J., Wullschleger, S. D., Gunderson C. A. \& Nietch, C. T. New Phytol. 131, 91-97 (1995).

10. Wullschleger, S. D., Post, W. M. \& King, A. W. in Biotic Feedbacks in the Global Climatic System. Will the Warming Feed the Warming? (eds Woodwell, G. M. \& Mackenzie, F. T.) 85-107 (Oxford Univ. Press, New York, 1995).

11. Pregitzer, K. S. et al. New Phytol. 129, 579-585 (1995)

12. Ceulemans, R., Jiang, X. N. \& Shao, B. Y. Ann. Bot. 75, 609-617 (1995)

13. Ceulemans, R. et al. Tree Physiol. 16, 61-68 (1996).

14. Mousseau, M. et al. in Carbon Dioxide and Terrestrial Ecosystems (eds Koch, G. W. \& Mooney, H. A.) 71-86 (Academic, San Diego, 1996).

15. Idso, S. B., Wall, G. W. \& Kimball, B. A. Envir. exp. Bot.
} 33, 367-375 (1993) constant leaf area, and therefore is more relevant to the response of trees in a forest where leaf area approaches a relatively constant value, constrained by available resources, particularly light, water and nutrients. The $29 \%$ increase in CPI is similar to the growth increases observed in many short-term studies with small seedlings, as well as to the amount of $\mathrm{CO}_{2}$ fertilization required to balance most global carbon budget models ${ }^{8,10}$.

The consistent response of the CPI to elevated $\mathrm{CO}_{2}$ suggests that sustained, moderate increases in tree growth can be expected in a $\mathrm{CO}_{2}$-enriched atmosphere. That is not to say, however, that this index alone predicts forest productivity. Root growth and heterotrophic respiration are not taken into account in the CPI. Environmental factors that reduce the leaf area of a forest stand, such as soil infertility or drought, will reduce productivity gains from the $29 \%$ enhancement suggested by the CPI.

This analysis gives rise to several hypotheses about tree responses which can be tested in larger-scale $\mathrm{CO}_{2}$-enrichment experiments in forests: for example, CPI will remain higher in elevated $\mathrm{CO}_{2}$ throughout stand development and canopy closure; and effects of other environmental factors on tree growth will be manifested primarily through changes in leaf area index. The separation of functional variables such as leaf physiology and wood production, and structural variables such as leaf area index, is the basic approach of a global productivity model ${ }^{3}$. The CPI provides a useful construct for organizing existing experimental data and future, large-scale forest exposure experiments along similar principles.

\section{R. J. Norby}

Environmental Sciences Division, Oak Ridge National Laboratory,

Oak Ridge, Tennessee 37831-6422, USA 